303. アイススケートの策国图的研究

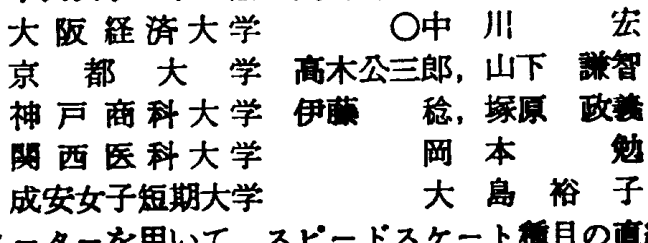
テレィーターを用いて、スピードスケート值目の直線 滑走動作の筋電四を記錄し，策の作用機度の面から梌时

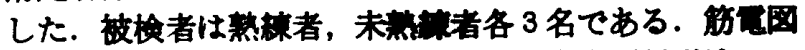

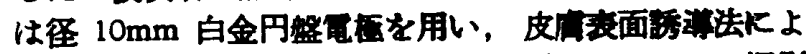

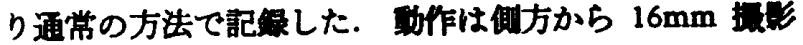
機で毎秒 32 コマで EMG と同時記皱した。 スケーテイ ンクの推進力を生み出すいわ的る “けり” の動作（図 1

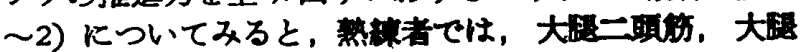

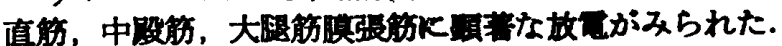

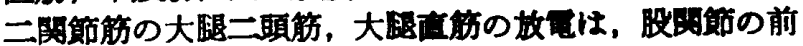

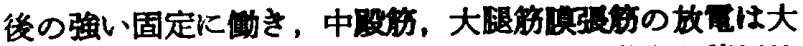
内枟筋の放電と交代していることから外枟動作を程标的 に行っていることがわかる．この間の㲜作を見ると，

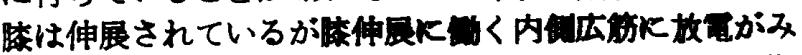

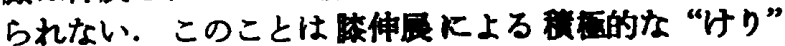
は行われていないるのと誟えられる。

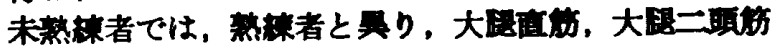

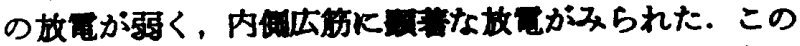
ことは，股飪の前後の固定が十分なされていないるの

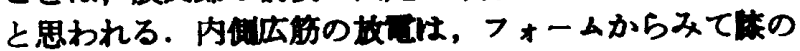

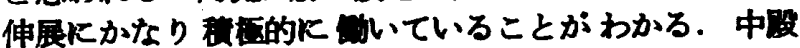

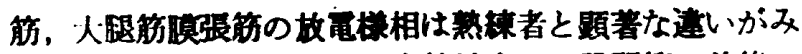

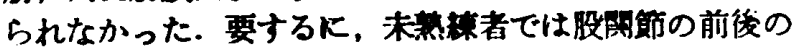
固定があまり强くなされず，外枟及ひ滕の伸展か殆んど 同時に行われていることがわかる. 彷来よりスケート滑

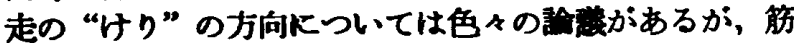

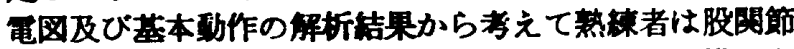

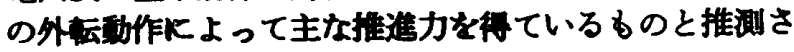
れる.

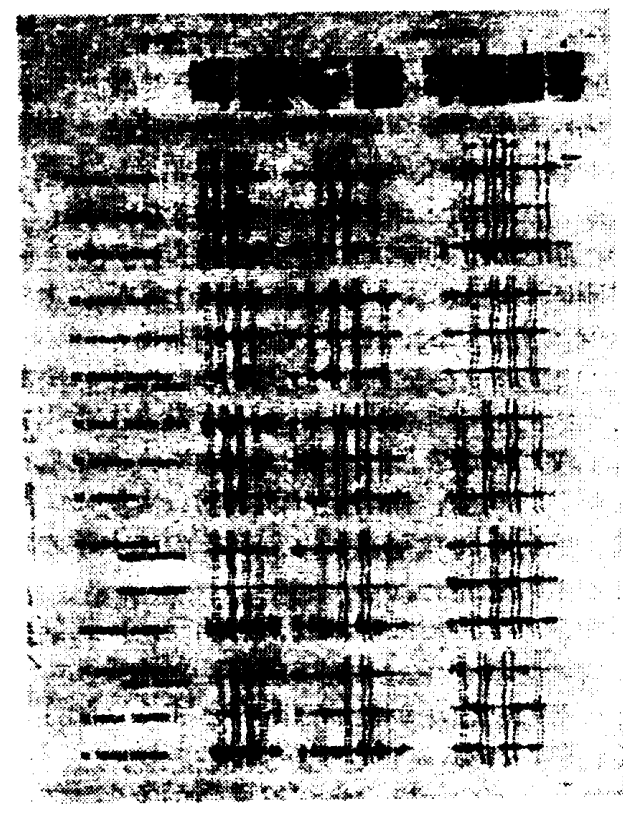

304. スケートの正的兴的开究

\section{その2 曲兴济走について}

都留文科大学 一木昭 男

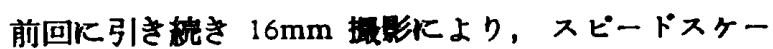

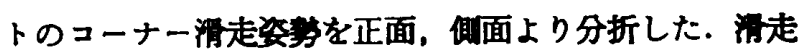
動作を右足のキックから左足の引き害せまでの一周期を 8 時点に分け，量心，滑走速度，姿等分折を行った．被 検者は大学スヶート部員 5 名について行った.

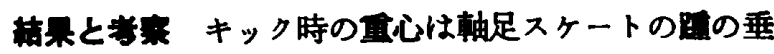
線上にみられ，引き奇世時はスケートの前 $1 / 3$ の垂線上 にみられる．重心高は前屈腰上前部にあり，走 時の上下動は程んどみられない，正面からは全身左㑯斜 の筑囲で，左・右の軸足とキック及び引き跍せにわずか の左右移動がられる。

滑走速度は 32/sec のスピードて掫㴟した際、キック 時 14〜16コマ，引き㟢世時8〜10コマである。これは 直線滑走とは逆の関係であった。一周期 46〜50 コマの 速度であった。

滑走姿答の分折角は表に示す通りである．正面から全 身，上体，局，軸脚の㑯斜をみるといつれの時点でる左 偭科である。その中でキック時に起き上り，引き㟢せに 左順が深くなる㑯向がみられる，側面から上体の前㑯は
わずかにキック時に前佰し，引き㨐世に起きる者がみら

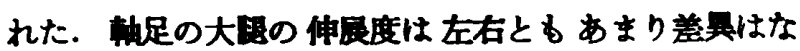
く，キック時下屈曲し，引き奇せ時飞伸展がみられる。 本の間闹度はキっク時飞拉し. 足くび角は两足フラット 時に小さくなる．梠のエッジは常に左足フウト，右足

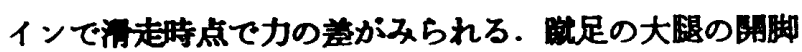
怯右足キック時に大きく，左足は小さい。これは交文し て既り迈むために抑制されるるので，直線清走特にはな

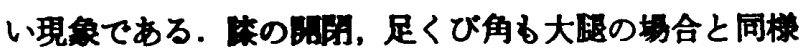

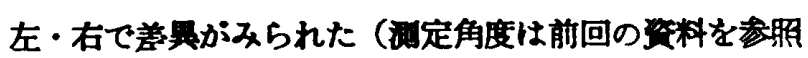
して下さい).

\begin{tabular}{|c|c|c|c|c|c|c|c|c|c|c|}
\hline & & & 1 & 2 & 3 & 4 & 5 & 6 & 7 & 8 \\
\hline 金 & $E$ & $E$ & 25 & 29 & 27 & 26 & 25 & 26 & 29 & 26 \\
\hline & 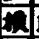 & 6 & $C$ & 68 & 69 & 66 & 59 & 57 & 67 & 65 \\
\hline & $\mathbb{E}$ & $E 4$ & 12 & 14 & 14 & 12 & 12 & 13 & 13 & 11 \\
\hline$m$ & 这 & $E n$ & 18 & 18 & 20 & 9 & 12 & 12 & 13 & 9 \\
\hline & $E$ & $E \%$ & 10 & 15 & \begin{tabular}{|l|}
18 \\
\end{tabular} & 19 & 10 & 15 & 18 & 16 \\
\hline & & $\pm n$ & 51 & 50 & 5 & 63 & & & & \\
\hline & & 51 & & & & & 52 & 55 & 56 & 64 \\
\hline & & & 115 & 115 & 116 & ins & & & & \\
\hline & & 11 & & & & & 119 & 117 & 115 & 114 \\
\hline & & 12 & 0 & $\infty$ & 5 & 53 & & & & \\
\hline & & 511 & & & & & 73 & 71 & 70 & 59 \\
\hline & & $E \pi$ & & & & & 100 & 98 & $T$ & 65 \\
\hline & & $5 \pi$ & 54 & 118 & 101 & 68 & & & & \\
\hline & & $5 \pi$ & & & & & 197 & 118 & 85 & 121 \\
\hline & & 51 & 156 & 157 & 139 & 137 & & & & \\
\hline 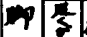 & & 19 & & & & & 54 & 74 & 79 & 65 \\
\hline & & $5=1$ & 65 & 99 & 78 & $\pi$ & & & & \\
\hline
\end{tabular}

